\title{
PENERAPAN MODEL PEMBELAJARAN INKUIRI DIPADU DENGAN MIND MAPPING UNTUK MENINGKATKAN KEMAMPUAN KOGNITIF SISWA KELAS XI MIPA 2 SMA N 6 SURAKARTA SEMESTER 2 TAHUN PELAJARAN 2014/2015
}

\section{IMPLEMENTATION OF INQUIRY LEARNING COMBINED WITH MIND MAPPING TO INCREASE COGNITIVE ABILITY IN CLASS XI MIPA 2 SMA N 6 SURAKARTA SEMESTER 2 IN THE ACADEMIC YEAR 2014/2015}

\author{
WINDY PURWATI, SLAMET SANTOSA, YUDI RINANTO \\ Program Studi Pendidikan Biologi \\ Fakultas Keguruan dan Ilmu Pendidikan \\ Universitas Sebelas Maret \\ Jl. Ir. Sutami 36 A, Surakarta, 57126, Indonesia \\ *Corresponding Author: windypurwatii@gmail.com
}

Manuscript received : 11 Januari 2016 Revision accepted: 22 Maret 2016

\begin{abstract}
This research was aimed to improve cognitive ability of student class XI MIPA 2 SMA Negeri 6 Surakarta academic year 2014/2015 through the implementation of inquiry learning model that is combined with mind mapping. This research was classroom action research that divided into two cycles. The subject of this research is the student of XI MIPA 2 SMA Negeri 6 Surakarta academic year 2014/2015. The method of data collection through tes, observation, interviews, and documentation. The data is analyzed with descriptive analytical technique and validated by triangulation technique.The result show that student cognitive ability is increased in pre-cycle, cycle I, cycle II. The average of students cognitive ability increase from pre-cycle $35,01 \%$ to $55,21 \%$ at cycle I, and 78,02 \% at cycle II. Remembering aspect increase from 40,40 \% to 88,88 $\%$. Understanding aspect increase from $37,87 \%$ to $82,31 \%$. Applying aspect increase from 46,46\% to 82,82 \%. Analyzing aspect increase from $29,29 \%$ to $73,73 \%$. Evaluating aspect increase from $26,76 \%$ to $71,20 \%$. Creating aspect increase from $29,29 \%$ to $69,18 \%$. This research's conclutions is the implementation of inquiry learning model that combined with mind mapping can improve cognitive ability of the student class XI MIPA 2 SMA Negeri 6 Surakarta.
\end{abstract}

Keywords : Inquiry, Mind Mapping, Cognitive Ability

\section{PENDAHULUAN}

Salah satu tantangan terbesar dalam dunia pendidikan saat ini adalah menghubungkan siswa dengan objek pembelajaran untuk memicu siswa agar mau belajar dan menyumbang dalam memperbaiki kualitas pendidikan (Madhuri, M., and Broussard, C. 2007).

Kualitas pendidikan di Indonesia masih jauh dari yang diharapkan. Pemerintah telah melakukan berbagai upaya untuk meningkatkan mutu pendidikan nasional, antara lain melalui berbagai pelatihan dan peningkatan kualifikasi guru, penyempurnaan kurikulum, pengadaan buku, alat pelajaran, dan perbaikan sarana prasarana pendidikan lainnya, namun berbagai indikator mutu pendidikan tersebut belum mampu menunjukkan peningkatan yang memadai (Nurhadi, 2005).
Rendahnya kualitas pendidikan juga ditunjukan dengan hasil observasi yang dilakukan di kelas XI MIPA 2 SMA Negeri 6 Surakarta diantaranya yaitu proses pembelajaran masih didominasi oleh guru, siswa kurang diberikan kesempatan untuk menggali pengetahuan dan mengaitkan konsep yang dipelajari ke dalam situasi yang berbeda sehingga konsep-konsep yang diajarkan menjadi kurang bermakna dan hanya bersifat hafalan saja. Hafalan yang dimiliki siswa hanya bersifat sementara sehingga berpengaruh kepada kemampuan kognitif siswa.

Kemampuan kognitif siswa juga dilihat dengan menggunakan tes kemampuan awal pada pokok bahasan sistem pencernaan. Soal-soal yang digunakan bertaraf C1-C6 dengan masing-masing aspek kognitif berjumlah 3 butir soal. Selain itu kemampuan kognitif juga dilakukan dengan menggunakan observasi berdasarkan instrument yang telah disediakan. 
BIO-PEDAGOGI 5(1): 15 - 19, April 2016

Hasil tes dan observasi kemampuan kognitif awal menunjukan bahwa kemampuan kognitif siswa memang rendah dengan penjabaran pada masingmasing aspek kognitif yaitu mengingat 40,40\%, memahami $37,87 \%$, mengaplikasikan $46,46 \%$, menganalisis $29,29 \%$ mengevaluasi $26,76 \%$, dan mencipta $29,29 \%$. Rata-rata kemampuan kognitif awal adalah $35,01 \%$.

Berdasarkan kajian terhadap hasil tes dan observasi, maka dilakukan wawancara terhadap guru dan beberapa siswa terkait permasalahan yang menjadi penyebab rendahnya kemampuan kognitif siswa kelas XI MIPA 2 SMA Negeri 6 Surakarta dalam pembelajaran biologi. Hasil wawancara dengan guru terkait rendahnya kemampuan kognitif yang dimiliki siswa kelas XI MIPA 2 SMA Negeri 6 Surakarta dikarenakan siswa memiliki kemampuan mengingat yang kurang dalam pelajaran biologi, sehingga daya serap dalam memahami materi biologi masih rendah. Siswa malas jika diminta untuk mencatat materi pelajaran.Kegiatan pembelajaran jarang memanfaatkan fasilitas laboratorium untuk melakukan kegiatan praktikum sehingga siswa kurang memahami materi pelajaran.

Hasil wawancara dengan siswa juga didapatkan bahwa model pembelajaran yang digunakan guru saat pembelajaran dianggap kurang bervariasi sehingga siswa merasa jenuh saat kegiatan pembelajaran berlangsung. Materi biologi juga sangat banyak dan abstrak sehingga sulit untuk dihafalkan dan siswa merasa kesulitan dalam memahami materi. Siswa juga mengatakan jarang mencatat saat pembelajaran karena merasa telah memiliki buku paket.

Hasil observasi, tes, dan wawancara menunjukan bahwa siswa kelas XI MIPA 2 memiliki kemampuan kognitif yang rendah. Kemampuan kognitif merupakan kemampuan yang berkenaan dengan hasil belajar intelektual yang terdiri dari enam aspek yaitu mengingat, memahami, mengaplikasikan, menganalisis, mengevaluasi, dan mencipta (Sudjana, 2009).

Langkah yang digunakan untuk mengatasi masalah yang ada di kelas XI MIPA 2 SMA Negeri 6 Surakarta adalah dengan menerapkan model pembelajaran inkuiri dipadu mind mapping. Model inkuiri menurut Gulo (2002) yaitu, inkuiri merupakan kegiatan pembelajaran yang melibatkan secara maksimal seluruh kemampuan peserta didik untuk mencari dan menyelidiki. Model inkuiri dapat digunakan untuk meningkatkan kemampuan kognitif, karena dalam pembelajaran inkuiri membantu siswa mengembangkan kemampuan berfikir kritis, analitis, berpikir kreatif, dan sikap ilmiah melalui keterlibatannya dalam hand-on activity (Gulo, 2002).
Model pembelajaran inkuiri dapat mengikutsertakan siswa dalam mencari informasi dan melakukan penyelidikan. Siswa dituntut aktif dengan mengajukan pertanyaan untuk memenuhi rasa ingin tahunya, sehingga siswa mampu menguasai materi dalam hal mengingat, memahami, menerapkan, menganalisis, mengevaluasi, bahkan mencipta. Pembelajaran yang seperti ini akan menjadi lebih bermakna.

Pembelajaran menjadi lebih bermakna apabila materi pelajaran dihubungan antara konsep satu dengan konsep lainnya. Hubungan antara konsepkonsep dalam suatu materi pelajaran dapat diwujudkan dalam bentuk rumus-rumus, grafik, bagan, poster, tabel, dan bentuk hubungan lainnya atau disebut dengan mind mapping. Buzan (2013) menyatakan bahwa mind mapping adalah cara termudah untuk menempatkan informasi kedalam otak dan mengambil informasi ke luar otak.

Inkuiri adalah proses belajar yang menonjolkan mental dan fisik sehingga memiliki kekurangan dalam hal mencatat materi. Catatan merupakan garis besar dari materi yang telah dipelajari. Kekurangan ini dapat diatasi dengan adanya mind map. Penggunaan mind mapping membantu siswa dalam membuat dokumentasi materi pelajaran dengan kreatif, memudahkan dalam hal mengingat dan menghubungkan sebuah ide dengan ide lainnya (Hilman, 2014).

\section{METODE PENELITIAN}

Penelitian ini dilaksanakan pada semester genap Tahun Pelajaran 2014/2015 di kelas XI MIPA 2 SMA Negeri 6 Surakarta yang beralamat di Jalan Mr. Sartono No. 30 Surakarta. Penelitian ini adalah penelitian tindakan kelas yang bertujuan untuk mengetahui penggunaan model pembelajaran inkuiri yang dipadu dengan mind mapping untuk meningkatkan kemampuan kognitif siswa kelas XI MIPA 2 SMA Negeri 6 Surakarta tahun pelajaran 2014/2015.

Prosedur dan langkah-langkah penelitian mengikuti Arikunto (2013) bahwa penelitian ini meliputi empat tahap, yaitu: tahap perencanaan tindakan, tahap pelaksanaan, tahap observasi dan refleksi.

Penerapan tindakan berupa model pembelajaran inkuiri yang dipadukan dengan mind mapping dan dilaksanakan dalam 2 siklus mulai dari tanggal 31 Maret 2015 sampai 9 April 2015. Subjek penelitian yaitu siswa kelas XI MIPA 2 SMA Negeri 6 Surakarta Tahun Pelajaran 2014/2015 yang berjumlah 33 siswa.

Sebelum dilaksanakan penelitian dilakukan tes awal sebagai dasar kemampuan kognitif siswa. Tes kemampuan kognitif dilakukan pada setiap akhir 


\section{Purwati-Penerapan Model Pembelajaran Inkuiri}

siklus untuk mengetahui peningkatan kemampuan kognitif siswa setelah diterapkannya model pembelajaran inkuiri dipadu dengan mind mapping.

Pengumpulan data menggunakan teknik tes dengan soal pilihan ganda bertipe C1 sampai dengan C6 menurut taksonomi Bloom dan teknik non tes dengan teknik observas, wawancara dan dokumentasi yang dilakukan pada saat proses pembelajaran. Teknik yang dilakukan untuk memeriksa validitas data yang digunakan dalam penelitia adalah triangulasi.

Langkah-langkah yang dilakukan dalam penelitian meliputi empat tahap yaitu: 1) perencanaan: tahap perencanaan yaitu menyusun Rencana Pelaksanaan Pembelajaran (RPP), menyusun dan mempersiapkan lembar observasi, dan wawancara untuk siswa, menyusun pedoman wawancara bagi guru, menyusun Lembar Kerja Siswa (LKS), menyiapkan alat untuk pembuatan mind mapping bagi siswa, menyusun soal tes untuk siswa yaitu soal tes akhir siklus I; 2) pelaksanaan: perencanaan yang telah disiapkan diterapkan dalam bentuk penerapan model inkuiri dipadu dengan mind mapping. Pelaksanaan tindakan diwujudkan dalam RPP; 3) Observasi: Observasi dilakukan dengan mengamati secara langsung bagaimana proses belajar mengajar dengan menerapkan model pembelajaran inkuiri dipadu dengan mind mapping. Fokus observasi yaitu kegiatan yang mencerminkan kemampuan kognitif siswa yang diamati dengan bantuan lembar observasi. Setiap kegiatan yang terjadi selama proses pembelajaran diusahakan dicatat seperti apa adanya dalam lembar observasi; 4) refleksi: kegiatan pada tahap ini adalah mengevaluasi proses dan dampak dari pelaksanaan tindakan. Refleksi dilakukan setelah akhir siklus. Refleksi dilakukan untuk mengetahui berhasil tidaknya pelaksanaan tindakan. Jika tindakan belum berhasil, maka perlu diadakan perbaikan pada siklus selanjutnya.

\section{HASIL DAN PEMBAHASAN}

Hasil penelitian menunjukan bahwa penerapan model pembelajaran inkuiri dipadu dengan mind mapping dapat meningkatkan kemampuan kognitif siswa. Pengukuran dilakukan dengan menggunakan instrumen berupa tes dan observasi pada saat kegiatan kegiatan pembelajaran. Peningkatan masing-masing aspek kemampuan kognitif terjadi pada setiap siklus dapat dilihat pada tabel 1 dan gambar 1.
Tabel 1. Perbandingan Kemampuan Kognitif Tiap Aspek Pada Masing-masing Siklus

\begin{tabular}{llccc}
\hline No. & $\begin{array}{l}\text { Aspek } \\
\text { Kognitif }\end{array}$ & $\begin{array}{c}\text { Pra } \\
\text { siklus }\end{array}$ & $\begin{array}{c}\text { Siklus } \\
\mathbf{1}\end{array}$ & $\begin{array}{c}\text { Siklus } \\
\mathbf{2}\end{array}$ \\
\hline 1. & Mengingat & 40.40 & 66.66 & 88.88 \\
2. & Memahami & 37.87 & 64.13 & 86.86 \\
3. & Mengaplikasikan & 46.46 & 56.56 & 78.27 \\
4. & Menganalisis & 29.29 & 51.00 & 73.73 \\
5. & Mengevaluasi & 26.76 & 49.49 & 71.20 \\
6. & Mencipta & 29.29 & 43.43 & 69.18 \\
\hline
\end{tabular}

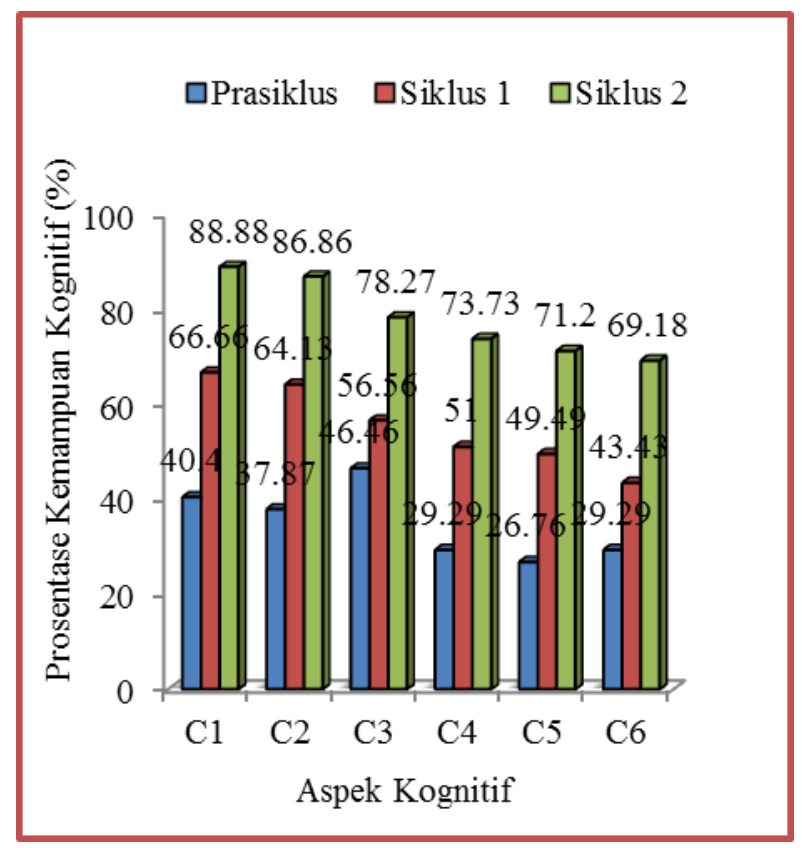

Gambar 1. Perbandingan Peningkatan Kemampuan Kognitif Siswa

Pada Tiap Siklus

Kemampuan kognitif menunjukan peningkatan pada setiap siklusnya. Siklus I menunjukan hasil bahwa masing-masing aspek kemampuan kognitif meningkat. Capaian persentase pada aspek mengingat sebesar $66,66 \%$, memahami $64,13 \%$, mengaplikasikan 56,56\%, menganalisis $51,00 \%$, mengevaluasi $49,49 \%$, dan mencipta $43,43 \%$.

Siklus II peningkatan kemampuan kognitif lebih besar dibandingkan dengan siklus I dengan capaian masing masing aspek yaitu mengingat $88,88 \%$, memahami $86,86 \%$, mengaplikasikan $78,27 \%$, menganalisis $73,73 \%$, mengevaluasi $71,20 \%$, dan mencipta $69,18 \%$. 
BIO-PEDAGOGI 5(1): 15 - 19, April 2016

Rata-rata kemampuan kognitif siswa pada akhir siklus II telah meningkat dari target yang diinginkan yaitu $\geq 75 \%$. Aspek memahami memiliki kenaikan yang paling tinggi yaitu mencapai $48,99 \%$, kemudian dibawahnya ada mengingat dengan kenaikan sebesar 48,48\%, dan dibawahnya ada menganalisis serta mengevaluasi dengan kenaikan sebesar 44,44\%, mencipta persentase kenaikanya sebesar 39,89\%, sedangkan mengaplikasikan memiliki persentase kenaikan paling kecil yaitu $31,81 \%$.

Peningkatan yang terjadi pada setiap siklus tidak lepas dari penerapan model pembelajaran inkuiri yang dipadu dengan mind mapping. Materi sistem ekskresi menjadi dasar dalam pembuatan rumusan masalah. Siswa melakukan kegiatan observasi pada materi sistem ekskresi untuk dapat merumuskan masalah. Siswa berdiskusi dengan kelompok yang telah ditentukan untuk bersama-sama menyusun hipotesis. Masing-masing kelompok membuat rancangan hipotesis, dan membuktikan hipotesis melalui percobaan. Hasil percobaan yang telah didapat kemudian dianalisis bersama dengan kelompok. Hasil analisis kelompok kemudia dijadikan sebagai dasar pembuatan mind mapping, setelah itu siswa mempresentasikan hasil percobaan.

Melalui inkuiri dipadu dengan mind mapping siswa akan terbiasa untuk melakukan kegiatan pembelajaran yang merupakan aspek dari kemampuan kognitif mulai dari mengingat sampai mencipta.

Hasil penelitian dengan menggunakan model pembelajaran inkuiri dipadu dengan mind mapping sejalan dengan penelitian sebelumnya yang dilakukan oleh Hilman (2014) Saat siswadiperhadapkan pada situasi yang menuntut kemandirian berpikir, pada saat itu pula siswa mengalami proses pengembangan kognitif yang lebih maju dari sebelumnya, sehingga kemampuan kognitif dapat meningkat.

Pembelajaran inkuiri memberikan kesempatan kepada siswa untuk dapat belajar mandiri dan bertanggungjawab, sehingga tiga kemampuan kognitif seperti menganalisis, mengevaluasi dan mencipta dapat meningkat (Rooney, 2009). Percobaan yang dilakukan dalam pembelajaran inkuiri mau tidak mau menuntut siswa untuk membaca buku-buku pengetahuan, merancang percobaan, dan mengevaluasi hasil percobaan, sehingga siswa akan terbiasa berfikir sekaligus melatih kemampuan kognitif (Gormally, C., Brickman, P., Hallar, B., and Armstrong, N. 2009)

Penggunaan mind mapping dalam proses pembelajaran ikut berperan dalam meningkatkan kemampuan kognitif. Rahayu, R., Suyitno, A., \& Sugiharti, E. (2012) menyatakan bahwa siswa yang difasilitasi dengan mind maping memperoleh prestasi belajar lebih baik daripada siswa yang diberi pembelajaran langsung. Penggunaan mind map membantu guru menyediakan pengalaman belajar yang mempermudah siswa membangun pengetahuannya sendiri sekaligus memudahkannya untuk mengingat

materi yang telah dipelajari.

Berdasarkan penelitian dari Rosciano, A. (2015) bahwa menggunakan mind mapping sebagai strategi pembelajaran aktif adalah teknik yang inovatif untuk memfasilitasi belajar siswa. Mind mapping dapat digunakan untuk mencatat, menyelesaikan tugas, mempersiapkan ujian, dan melatih dalam menganalisis.

\section{SIMPULAN}

Berdasarkan hasil penelitian dapat disimpulkan bahwa penerapan model inkuiri dipadu dengan mind mapping mampu meningkatkan kemampuan kognitif siswa kelas XI MIPA 2 SMA N 6 Surakarta Tahun Pelajaran 2014/2015 secara efektif.

\section{DAFTAR PUSTAKA}

Arikunto, S., Suhardjono., dan Supardi. (2010). Penelitian Tindakan Kelas. Jakarta: Bumi Aksara.

Buzan, T. (2013). Buku Pintar Mind Mapping. Jakarta: Gramedia Pustaka Utama.

Gormally, C., Brickman, P., Hallar, B., and Armstrong, N. (2009). Effects of Inquiry-based Learning on Students Science Literacy Skills and Confidence. International Journal for the Scholarship of Teaching and Learning. 3 (2).

Gulo. (2002). Strategi Belajar Mengajar. Jakarta: Grafindo

Hilman. (2014). Pengaruh Pembelajaran Inkuiri Terbimbing dengan Mind Map terhadap Keterampilan Proses Sains dan Hasil Belajar IPA. Jurnal Pendidikan Sains. 2 (4), 221-229.

Madhuri, M., and Broussard, C. (2007). Do I Need to Know This for the Exam?. Using Popular Media, Inquirybased Laboratories, and a Community of Scientific Practice to Motivate Students to Learn Developmental Biology. Life Sciences Education. 7: 36-44.

Nurhadi. (2005). Kurikulum 2004. Jakarta: Grasindo

Rahayu, R., Suyitno, A., \& Sugiharti, E. 2012. Keefektifan Pembelajaran Kooperatif Model Mind Map Berbantukan CD Pembelajaran terhadap Hasil Belajar. Unnes Journal of Mathematics Education. (Online),Vol.1(1),(http://journal.unnes.ac.id/sju/inde ks.php/ujme, diakses 06 Juli 2015).

Rooney, C. (2009). How am I using inquiry-based learning to improve my practice and to encourage higher order thinking among my students of mathematics?. Educational Journal of Living Theories. 5 (2): 99127

Rosciano, A. (2015). The effectiveness of mind mapping as an active learning strategy among associate degree nursing students. Teaching and Learning in Nursing. 10: 93-99 


\section{Purwati-Penerapan Model Pembelajaran Inkuiri}

Sudjana, N., dan Rivai, A. (2009). Media Pengajaran. Bandung: Sinar Baru Algensindo

Suryani, N., Agung, L. (2012). Strategi Belajar-Mengajar. Yogyakarta: Penerbit Ombak 